\title{
PENGARUH MINAT BELAJAR, KEPERCAYAAN DIRI, DISIPLIN BELAJAR, LINGKUNGAN SEKOLAH DAN BULLYING TERHADAP PERILAKU BELAJAR KELOMPOK KELAS VII DI SMP N 6 KOTA SOLOK
}

\author{
Vini Aryulia, Ansofino, Jimi Ronald \\ Program Studi Pendidikan Ekonomi STKIP PGRI Sumatera Barat \\ aryuliavini97@gmail.com
}

\begin{abstract}
This study aims to analyze: 1) the effect of partial interest in learning on group learning behavior, 2) the effect of partial self-confidence on group learning behavior, 3) the effect of partial learning discipline on group learning behavior, 4) the effect of partially school environment on behavior group learning, 5) the effect of bullying partially on group learning behavior and 6) the influence of learning interest, self-confidence, learning discipline, school environment and bullying simultaneously on group learning behavior. The results of the study are first, interest in learning greatly influences group learning behavior. Both selfconfidence are very influential on group learning behavior. The three learning disciplines are very influential on group learning behavior. The four school environments affect group learning behavior. Fifth, bullying is very influential on group learning behavior. The six learning interests, self-confidence, learning discipline, school environment and bullying affect group learning behavior.

Keywords : Learning Interests, Self Confidence, Learning Discipline, School Environment, Bullying, Group Learning Behavior.

\section{PENDAHULUAN}

Berkembangnya ilmu pengetahuan dan teknologi yang begitu pesat di era globalisasi ini. Kita dituntut untuk menghadapi perkembangan yang begitu pesat. Oleh karena itu kita harus membekali diri kita dengan memiliki kemampuan dan keterampilan dalam menghadapi perubahan tersebut,

salah satu caranya adalah melalui pendidikan.

Berdasarkan Undang-Undang RI Nomor 20 tahun 2003 tentang Sistem Pendidikan Nasional Bab I pasal I (I) menjelaskan bahwa: Pendidikan didefinisikan sebagai usaha sadar dan tercerna untuk mewujudkan suasana belajar dan proses pembelajaran agar peserta didik mengembangkan
\end{abstract}


potensi dirinya untuk memiliki kekuatan spiritual keagamaan, pengendalian diri, kepribadian, kecerdasan, akhlak mulia, serta keterampilan yang diperlukan dirinya, masyarakat, bangsa dan negara.

Belajar merupakan suatu proses yang menyebabkan terjadinya suatu perubahan tingkah laku karena adanya reaksi terhadap suatu situasi tertentu yang terjadi secara internal didalam diri seseorang.

Minat belajar timbul ketika ada ketertarikan siswa dalam pelajaran atau materi yang disampaikan oleh guru. Menurut Mahfudh Shalahuddin dalam Yasinta \& Fernandes, (2020), minat adalah perhatian yang mengandung unsur-unsur perasaan. Dengan begitu minat sangat menentukan sikap yang menyebabkan seseorang aktif dalam suatu pekerjaan atau dengan kata lain, minat dapat menjadi sebab dari suatu kegiatan.

Faktor internal yang dapat mempengaruhi motivasi belajar siswa adalah kepercayaan diri.
Menurut Fatimah

(2006:59) kepercayaan diri adalah sikap positif seorang individu yang memampukan dirinya untuk mengembangkan penilaian positif baik terhadap diri sendiri maupun lingkungan atau situasi yang dihadapinya.

Menurut Arikunto dalam Sari \& Hadijah, (2017) di dalam pembicaraan disiplin dikenal dua istilah yang pengertiannya hampir sama tapi pembentukannya secara berurutan. Kedua istilah itu adalah disiplin dan ketertiban, ada juga yang meggunakan istilah siasat dan ketertiban.Ketertiban menunjuk pada kepatuhan seseorang dalam mengikuti peraturan dan tata tertib karena didorong oleh sesuatu dari luar, misalnya karena ingin mendapat pujian dari atasan.Selanjutnya pengertian disiplin atau siasat menunjuk pada kepatuhan seseorang dalam mengikuti tata tertib karena didorong kesadaran yang ada pada kata hatinya. Itulah sebabnya biasanya ketertiban itu terjadi dahulu, kemudian berkembang menjadi siasat. 


\section{METODE PENELITIAN}

Sesuai dengan masalah yang diteliti, maka jenis penelitian ini adalah penelitian asosiatif. Penelitian akan dilakukan pada SMP Negeri 6 Kota Solok dilaksanakan pada bulan Februari 2021. Populasi pada penelitian ini yaitu rincian siswa dan tingkat. pendapatan orang tua kelas VII IPS SMP N 6 Kota Solok. Menurut Sugiyono (2014) sampel adalah bagian dari jumlah dan karakteristik yang dimiliki oleh populasi tersebut. Teknik pengambilan sampel sebanyak 81 siswa diambil secara acak yaitu pengambilan sampel dari anggota populasi dilakukan secara acak.

\section{HASIL DAN PEMBAHASAN}

Hasil

1) Analisis Regresi Linear Berganda

Analisis regresi linear berganda keseluruhan dalam penelitian ini menguji Pengaru hminat belajar, kepercayaan diri, disiplin belajar, lingkungan sekolah dan bullying terhadap perilaku belajar kelompok di smp negeri 6 kota solok. Berikut hasil pengolahan data :

Tabel 1. Hasil Analisis Regresi Linear Berganda Keseluruhan

\begin{tabular}{ccccc}
\hline \hline Variable & Coefficient & Std. Error & t-Statistic & Prob. \\
\hline \hline C & 6.648759 & 2.587752 & 2.569319 & 0.0122 \\
Minat Belajar & 0.336558 & 0.059150 & 5.689894 & 0.0000 \\
Kepercayaan Diri & 0.202116 & 0.049091 & 4.117173 & 0.0001 \\
Disiplin Belajar & 0.235326 & 0.055994 & 4.202707 & 0.0001 \\
Lingkungan Sekolah & 0.113274 & 0.034483 & 3.284925 & 0.0016 \\
Bullying & -0.090801 & 0.023293 & -3.898158 & 0.0002
\end{tabular}

Sumber: Olahan Data Primer, 2021

Berdasarkan hasil yang terdapat $\mathrm{Y}=\mathrm{a}+\mathrm{b}_{1} \mathrm{X}_{1}+\mathrm{b}_{2} \mathrm{X}_{2}+\mathrm{b}_{3} \mathrm{X}_{3}+\mathrm{b}_{4} \mathrm{X}_{4}$ pada Tabeldi atas, maka dapat $+b_{5} X_{5}$ dirumuskan persamaan regresi linear $\mathrm{Y}=6,648+0,336 \mathrm{X}_{1}+0,202 \mathrm{X}_{2}+0,235 \mathrm{X}$ berganda sebagai berikut: ${ }_{3}+0,113 \mathrm{X}_{4}-0,090 \mathrm{X}_{5}$ 
1. Dari model persamaan regresi linear berganda di atas dapat diketahui bahwa nilai konstanta sebesar 6,648, yang berarti bahwa tanpa adanya pengaruh dari variable minat belajar, kepercayaan diri, disiplin belajar, lingkungan sekolah dan bullying maka perilaku belajar kelompok berkelompok bernilai 6,648.

2. Koefisien regresi variabel minat belajar $\left(\mathrm{X}_{1}\right)$ sebesar 0,336 . Hal ini berarti adanya pengaruh minat belajar terhadap perilaku belajar kelompok berkelompok (Y), apabila nilai minat belajar meningkat sebesar satu satuan maka perilaku belajar kelompok berkelompokkan meningkat sebesar 0,336 dalam setiap satuannya. Dengan asumsi variabel lain tidak mengalami perubahan atau konstan.

3. Koefisien regresi variabel kepercayaan diri $\left(\mathrm{X}_{2}\right)$ sebesar 0,202 . Hal ini berarti adanya pengaruh kepercayaan diri terhadap perilaku belajar kelompok (Y), apabila nilai kepercayaan diri meningkat sebesar satu satuan maka perilaku belajar kelompok berkelompokakan meningkat sebesar 0,202 dalam setiap satuannya. Dengan asumsi variabel lain tidak mengalami perubahan atau konstan.

4. Koefisien regresi variabel disiplin belajar $\left(\mathrm{X}_{3}\right)$ sebesar 0,235 . Hal ini berarti adanya pengaruh disiplin belajar terhadap perilaku belajar kelompok berkelompok (Y), apabila nilai disiplin belajar meningkat sebesar satu satuan maka perilaku belajar kelompok berkelompokakan meningkat sebesar 0,235 dalam setiap satuannya. Dengan asumsi variabel lain tidak mengalami perubahan atau konstan.

5. Koefisien regresi variabel lingkungan sekolah $\left(\mathrm{X}_{4}\right)$ sebesar 0,113. Hal ini berarti adanya pengaruh lingkungan sekolah terhadap perilaku belajar kelompok berkelompok (Y), apabila nilai lingkungan sekolah meningkat sebesar satu satuan 
maka perilaku belajar kelompok berkelompokakan meningkat sebesar 0,113 dalam setiap satuannya. Dengan asumsi variabel lain tidak mengalami perubahan atau konstan.

6. Koefisien regresi variabel bullying $\left(\mathrm{X}_{5}\right)$ sebesar $-0,090$. Hal ini berarti adanya pengaruh bullying terhadap perilaku belajar kelompok berkelompok (Y), apabila nilai bullying menurun sebesar satu satuan maka perilaku belajar kelompok berkelompokakan meningkat sebesar 0,090 dalam setiap satuannya. Dengan asumsi variabel lain tidak mengalami perubahan atau konstan.

1. Pengaruh Minat Belajar Terhadap Perilaku belajar kelompok Siswa Kelas VII Pada Mata Pelajaran IPS di SMP N 6 Kota Solok

Berdasarkan hasil pengujian hipotesis pertama bahwa minat belajar berpengaruh signifikan terhadap perilaku belajar kelompok di smp negeri 6 kota solok. Koefisien regresi minat belajar terhadap perilaku belajar kelompok sebesar
0,0,336. Nilai koefisien ini signifikan karena nilai $t_{\text {hitung }}$ sebesar 5,689> $t_{\text {tabel }}$ sebesar 1,992 sedangkan nilai signifikan $0,001<\alpha 0,05$. Dengan demikian dapat dikatakan bahwa terdapat pengaruh antara minat belajar terhadap perilaku belajar kelompok.

Sejalan dengan penelitian sebelumnya yang dilakukan oleh Lisa Princess Miranda, (2017) tentang Pengaruh lingkungan sekolah dan minat belajar perilaku belajar kelompok berkelompok di kelas $\mathrm{X}$ SMA Negeri 3 Bontang diperoleh hasil terdapat pengaruh minat belajar terhadap perilaku belajar kelompok berkelompok siswa.

2. Pengaruh Kepercayaan Diri Terhadap Perilaku belajar kelompokSiswa Kelas VII Pada Mata Pelajaran IPS di SMP N 6 Kota Solok

Berdasarkan hasil pengujian hipotesis kedua bahwa kepercayaan diri berpengaruh signifikan terhadap perilaku belajar kelompok di smp negeri 6 kota solok. Koefisien regresi kepercayaan diriterhadap perilaku belajar kelompok sebesar 0,202. Nilai koefisien ini signifikan karena 
nilai $t_{\text {hitung }}$ sebesar sebesar 4,117> $t_{\text {tabel }}$ sebesar 1,992. Dikatakan bahwa terdapat pengaruh antara kepercayaan diri terhadap perilaku belajar kelompok.

Sejalan dengan penelitian sebelumnya yang dilakukan oleh Petrus Galih Pramono Raharjo dan Arif Marwanto, (2015) tentang Pengaruh kepercayaan diri dan konformitas teman sebaya terhadap perilaku belajar kelompok berkelompok siswa kelas XI jurusan teknik dipeorleh hasil terdapat pengaruh kepercayaan diri terhadap perilaku belajar kelompok berkelompok siswa.

3. Pengaruh Disiplin Belajar Terhadap Perilaku belajar kelompok Siswa Kelas VII Pada Mata Pelajaran IPS di SMP N 6 Kota Solok

Berdasarkan hasil pengujian hipotesis ketiga bahwa disiplin belajar berpengaruh signifikan terhadap perilaku belajar kelompok di smp negeri 6 kota solok. Koefisien regresi disiplin belajar terhadap perilaku belajar kelompok sebesar 0,235 . Nilai koefisien ini signifikan karena nilai $t_{\text {hitung }}$ sebesar 4,202> $t_{\text {tabel }}$ sebesar 1,992 sedangkan nilai signifikan $\quad 0,001<\alpha 0,05$. Dengan demikian dapat dikatakan bahwa terdapat pengaruh antara disiplinbelajar terhadap perilaku belajar kelompok.

Sejalan dengan penelitian sebelumnya yang dilakukan oleh Ismatul Anwaroti, (2020) tentang Pengaruh konsep diri terhadap disiplin belajar siswa kelas VII di SMP Negeri 2 Ponorogo Tahun Ajaran 2019/2020 diperoleh terdapat pengaruh disiplin belajar terhadap perilaku belajar kelompok berkelompok.

4. Pengaruh Lingkungan Sekolah Terhadap Perilaku belajar kelompok Siswa Kelas VII Pada Mata Pelajaran IPS di SMP N 6 Kota Solok

Berdasarkan hasil pengujian hipotesis keempat bahwa lingkungan sekolah berpengaruh signifikan terhadap perilaku belajar kelompok di smp negeri 6 kota solok. Koefisien regresi lingkungan sekolah terhadap perilaku belajar kelompok sebesar 0,113 . Nilai koefisien ini signifikan karena nilai $t_{\text {hitung }}$ sebesar 3,284> $t_{\text {tabel }}$ sebesar 1,992 sedangkan nilai 
signifikan $0,001<\alpha 0,05$. Dengan demikian dapat dikatakan bahwa terdapat pengaruh antara lingkungan sekolah terhadap perilaku belajar kelompok.

Sejalan dengan penelitian sebelumnya yang dilakukan oleh Lisa Princess Miranda, (2017) tentang Pengaruh lingkungan sekolah dan minat belajar perilaku belajar kelompokdi kelas X SMA Negeri 3 Bontang diperoleh hasil terdapat pengaruh ligkungan sekolah dega perilaku belajar kelompok berkelompok.

5. Pengaruh bullying Terhadap Perilaku belajar kelompok Siswa Kelas VII Pada Mata Pelajaran IPS di SMP N 6 Kota Solok

Berdasarkan hasil pengujian hipotesis kelimat bahwa bullying berpengaruh signifikan terhadap perilaku belajar kelompok di smp negeri 6 kota solok. Koefisien regresi bullying terhadap perilaku belajar kelompok sebesar -0,090. Nilai koefisien ini signifikan karena nilai $t_{\text {hitung }}$ sebesar $-3,898<t_{\text {tabel }}$ sebesar 1,992 sedangkan nilai signifikan $0,001<\alpha 0,05$. Dengan demikian dapat dikatakan bahwa terdapat pengaruh antara bullying terhadap perilaku belajar kelompok.

Sejalan dengan penelitian sebelumnya yang dilakukan oleh Dodik Djauhari, Susi Ida Wardani, (2017) tentang Pengaruh Bullying Dan Harapan Orang Tua Terhadap Prestasi Terhadap Perilaku belajar kelompokkelompok Pada Siswa diperoleh terdapat pengaruh bullying terhadap perilaku belajar kelompok kelompok.

\section{PEMBAHASAN}

1. Hipotesis 1, terdapat pengaruh antara minat belajar $\left(\mathrm{X}_{1}\right)$ terhadap perilaku belajar kelompok berkelompok (Y). Diperoleh nilai koefisien regresi minat belajar sebesar $0,0,336$ dan nilai $t_{\text {hitung }}$ sebesar 5,689> $t_{\text {tabel }}$ sebesar 1,992 sedangkan nilai signifikan $0,000<\alpha 0,05$, berarti $\mathrm{H}_{\mathrm{a}}$ diterima dan $\mathrm{H}_{\mathrm{o}}$ ditolak dengan demikian dapat dikatakan bahwa terdapat pengaruh antara minat belajar terhadap perilaku belajar.

2. Hipotesis 2, terdapat pengaruh antara kepercayaan diri $\left(\mathrm{X}_{2}\right)$ 
terhadap perilaku belajar kelompok berkelompok (Y). Diperoleh nilai koefisien regresi kepercayaan diri sebesar 0,202 dan nilai $t_{\text {hitung }}$ sebesar 4,117> $t_{\text {tabel }}$ sebesar 1,992 sedangkan nilai signifikan $0,001<\alpha 0,05$, berarti $H_{a}$ diterima dan $\mathrm{H}_{\mathrm{o}}$ ditolak dengan demikian dapat dikatakan bahwa terdapat pengaruh antara kepercayaan diri terhadap perilaku belajar.

3. Hipotesis 3, terdapat pengaruh antara disiplin belajar $\left(\mathrm{X}_{3}\right)$ terhadap perilaku belajar kelompok berkelompok (Y). Diperoleh nilai koefisien regresi disiplin belajar sebesar 0,235 dan nilai $t_{\text {hitung }}$ sebesar 4,202> $\mathrm{t}_{\text {tabels }}$ sebesar 1,992 sedangkan nilai signifikan $0,001<\alpha 0,05$, berarti $\mathrm{H}_{\mathrm{a}}$ diterima dan $\mathrm{H}_{\mathrm{o}}$ ditolak dengan demikian dapat dikatakan bahwa terdapat pengaruh antara disiplin belajar terhadap perilaku belajar.

4. Hipotesis 4, terdapat pengaruh antara lingkungan sekolah $\left(\mathrm{X}_{4}\right)$ terhadap perilaku belajar kelompok berkelompok (Y).
Diperoleh nilai koefisien regresi lingkungan sekolah sebesar 0,113 dan nilai $t_{\text {hitung }}$ sebesar 3,284> $t_{\text {tabel }}$ sebesar 1,992 sedangkan nilai signifikan 0,016< $\alpha 0,05$, berarti $\mathrm{H}_{\mathrm{a}}$ diterima dan $\mathrm{H}_{\mathrm{o}}$ ditolak dengan demikian dapat dikatakan bahwa terdapat pengaruh antara lingkungan sekolah terhadap perilaku belajar.

5. Hipotesis 5, terdapat pengaruh antara bullying $\left(\mathrm{X}_{5}\right)$ terhadap perilaku belajar kelompok berkelompok (Y). Diperoleh nilai koefisien regresi bullying sebesar $-0,090$ dan nilai $\mathrm{t}_{\text {hitung }}$ sebesar $3,898<\mathrm{t}_{\text {tabel }} \quad$ sebesar $\quad 1,992$ sedangkan nilai signifikan $0,002<\alpha 0,05$, berarti $H_{a}$ diterima dan $\mathrm{H}_{\mathrm{o}}$ ditolak dengan demikian dapat dikatakan bahwa terdapat pengaruh antara bullying terhadap perilaku belajar. 


\section{KESIMPULAN}

Berdasarkan hasil analisis data yang telah dilakukan dapat disimpulkan sebagai berikut:

1. Minat belajar sangat berpengaruh terhadap perilaku belajar berkelompok, pengaruh yang lebih besar terdapat pada sampel keluarga dengan orang tua berpendapatan rendah dengan nilai koefisien sebesar 0,364617 , artinya perilaku belajar kelompok dipengaruhi oleh minat belajar sebesar 0,364617 .

2. Kepercayaan diri sangat berpengaruh terhadap perilaku belajar berkelompok, pengaruh yang lebih besar terdapat pada sampel keluarga dengan orang tua berpendapatan tinggi dengan nilai koefisien sebesar 0,261009, artinya perilaku belajar kelompok dipengaruhi oleh kepercayaan diri sebesar 0,261009.

3. Disiplin belajar sangat berpengaruh terhadap perilaku belajar berkelompok, pengaruh yang lebih besar terdapat pada sampel keluarga dengan orang tua berpendapatan rendah dengan nilai koefisien sebesar 0,269526, artinya perilaku belajar kelompok dipengaruhi oleh disiplin belajar sebesar 0,269526.

4. Lingkungan sekolah sangat berpengaruh terhadap perilaku belajar berkelompok, pengaruh yang lebih besar terdapat pada sampel keluarga dengan orang tua berpendapatan rendah dengan nilai koefisien sebesar 0,160477 , artinya perilaku belajar kelompok dipengaruhi oleh lingkungan sekolah sebesar 0,160477 .

5. Bullying sangat berpengaruh terhadap perilaku belajar berkelompok, pengaruh yang lebih besar terdapat pada sampel keluarga dengan orang tua berpendapatan rendah dengan nilai koefisien sebesar $-0,100476$, artinya perilaku belajar kelompok dipengaruhi oleh bullying sebesar $-0,100476$.

6. Minat belajar, kepercayaan diri, disiplin belajar, lingkungan sekolah dan bullying berpengaruh terhadap perilaku belajar dengan 
nilai Fhitung 67,780> Ftabel 2,49 dan nilai signifikan $0,000<0,05$. $\mathrm{Hal}$ ini berarti $\mathrm{HO}$ ditolak dan $\mathrm{Ha}$ diterima.

\section{DAFTAR PUSTAKA}

Ansofino.(2016).Ekonometrika (1 st ed.)

www.penerbitadeepublish.com

Ansofino dan Zusmelia (2019). Agro Bussines Development nexus tourism inwest sumatera province. Universitas islam Bandung (Unisba) Retrived from

http://ejournal.unisba.ac.id/inde x.php/mimbar/articel/view/411 $1 / \mathrm{pdf}$

Agustin, V. (2013). Perilaku belajar kelompok Siswa Sma Negeri Di Kota Padang Serta Upaya Pencegahan Oleh Guru Bk.Konselor, 2(1), 71-75. https://doi.org/10.24036/02013 21827-0-00

Ahmad. (2014). Hubungan Antara Self Efficacy Dengan Perilaku Sehat. Journal Psikologi Klinis Dan Kesehatan Mental, 3 (2), 85-89.

Alwisol. (2009). Self efficacy anak didik pemasyarakatan di Lapas anak kelas IIA Blitar. Retrieved from, Http://E theses.UinMalang. Ac.Id/1236 /6/11410061_Bab_2.Pdf., 1339.
Amri, S. (2018). Pengaruh Kepercayaan Diri ( Self Confidence ) Berbasis Ekstrakurikuler Pramuka Terhadap Prestasi Belajar Matematika Siswa Sma Negeri 6 Kota Bengkulu.Jurnal Pendidikan Matematika Raflesia., 03(02).

Fadrian. (2015). Pengaruh Kemandirian Belajar, Disiplin Belajar Dan Motivasi Berprestasi Terhadap Perilaku belajar kelompok Mahasiswa Fakultas Ekonomi Universitas Negeri Padang. Jurnal Kajian Pendidikan Ekonomi, 2(1). http://ejournal.unp.ac.id/index. php/mpe/article/download/586 $8 / 4587$

Fatimah, E. (2006). Psikologi Perekembangan Peserta Didik. PT. Pustaka Setia.

Ghozali. (2011). Aplikasi Analisis Multivariate Dengan Program SPSS. Universitas Diponegoro.

Herawati, M. (2019). Akademik Peserta Didik Smk Islam Ruhama. 2, 646-655.

Heru. (2017). Journal of Education and Development. Research and Development Journal of Education, 4(2), 63-74.

Influence, T. H. E., Self, O. F., Conformity, P., \& Cheating, O. N. (2014). Pengaruh kepercayaan diri dan konformitas teman sebaya 
terhadap perilaku menyontek siswa kelas xi jurusan teknik pengelasan. 255-262.

Laa, N, Winata, H., \& Meilani, R. I. (2017). Pengaruh Model Pembelajaran Kooperatif Tipe Student Teams Achievement Division Terhadap Minat Belajar Siswa.Jurnal Pendidikan Manajemen Perkantoran,2(2), 139.https://doi.org/10.17509/jp m.v2i2.8115

Motivasi, D. A. N., \& Terhadap, B. (2015). Menyontek Pada Mahasiswa Program Program Studi Pendidikan Ekonomi 2015.

Nugroho, M. B. (2013). Journal of Chemical Information and Modeling, 53(9), 1689-1699. https://doi.org/10.1017/CBO97 81107415324.004

Nursobah. (2009). Pengaruh Persepsi Siswa Tentang Iklim Sekolah Dan Kemandirian Belajar Terhadap Hasil Belajar Siswa Pada Mata Pelajaran Ekonomi Kelas XI IPS SMA N 1 Pariangan.Economic and Economic Education, 4(2).

Pasveer, J. (2004). Abstrak. The Djief Hunters, 26,000 Years of Rainforest Exploitation on the Bird's Head of Papua, Indonesia, 3(1), 355-358. https://doi.org/10.1201/b17006 $-13$
Pratama, I., Said, A., \& Erlamsyah. (2019). Efektivitas Layanan Penguasaan Konten Melalui Bimbingan Kelompok Belajar Dalam Mengurangi Perilaku Menyontek Siswa Saat Ujian.Jurnal Neo Konseling.

Purba, lili sari A., \& Harahap, K. (2019). Journal of Chemical Information and Modeling, 53(9), 1689-1699. https://doi.org/10.1017/CBO97 81107415324.004

Sari, B. P., \& Hadijah, H. S. (2017). Meningkatkan Disiplin Belajar Siswa melalui Manajemen Kelas.Jurnal Pendidikan Manajemen Perkantoran, 2(2), 122.

https://doi.org/10.17509/jpm.v $2 \mathrm{i} 2.8113$

Siregar. (2013). Statistik Parametrik untuk Penelitian Kuantitatif. Aksara Bumi.

Sugiyono. (2014). Metode Penelitian Kuantitatif, kualitatif, dan R\&D.pdf. Alfabeta.

Widarjono. (2013). Ekonometrika Teori dan Aplikasi untuk Ekonomi dan Bisnis. FE UI.

Yasin, F. (2011). Penumbuhan Kedisiplinan Sebagai Pembentukan Karakter Peserta Didik Di Madrasah.ElHikmah: Jurnal Kependidikan Dan Keagamaan, IX(1), 241948. 